\title{
Effects of Hizikia fusiforme Extracts on Adipocyte Differentiation and Adipogenesis in 3T3-L1 Preadipocytes
}

\author{
Eun Ok Choi ${ }^{1,2}$, Hyang Suk Kim,2, Min Ho Han ${ }^{3}$, Yung Hyun Choi ${ }^{2,3,4}$, Byung Woo Kim, \\ Jinah Hwang ${ }^{6}$ and Hye Jin Hwang ${ }^{1,4}$ * \\ ${ }^{1}$ Department of Food and Nutrition, ${ }^{2}$ Anti-aging Research Center, ${ }^{3}$ Department of Oriental Medicine, ${ }^{4}$ Blue-Bio Industry Regional Innovation \\ Center, ${ }^{5}$ Department of Life Science and Biotechnology, Dongeui University, Busan 614714, Korea \\ ${ }^{6}$ Department of Food and Nutrition, Myongii University, Gyeonggi-do 449-728, Korea
}

Received August 31, 2012 /Revised September 27, 2012 /Accepted September 28, 2012

\begin{abstract}
The present study was conducted to evaluate the effects of various extracts of Hizikia fusiforme on the anti-obesity effects in 3T3-L1 preadipocytes. We used $H$. fusiforme extracts from ethanol (EEHF), dichloromethane (CFHF), ethyl acetate (EAFHF), butanol (BFHF), and water (WFHF). Treatment with these extracts significantly suppressed terminal differentiation of 3T3-L1 preadipocytes in a dose-dependent manner as confirmed by a decrease in lipid droplet content through Oil Red $\mathrm{O}$ staining; this effect was higher in WFHF than in other extracts. The concentrations of cellular triglyceride were also reduced in 3T3-L1 cells by exposure with these extracts, especially when compared with the controls. Treatment with $200 \mu \mathrm{g} / \mathrm{ml}$ of WFHF and CFHF caused approximately $42.6 \%$ and $23.7 \%$ reduction, respectively. In addition, the extracts of $H$. fusiforme significantly reduced the expression levels of key pro-adipogenic transcription factors, including peroxisome proliferator-activated receptor $\gamma(\mathrm{PPAR} \gamma)$ and CCAAT/enhancer binding proteins a $(\mathrm{C} / \mathrm{EBPa})$ and $\mathrm{C} / \mathrm{EBP} \beta$ as compared with controls. Accordingly, our data indicated that WFHF has a preeminent effect on inhibition of adipocyte differentiation among various extracts, and $H$. fusiforme extracts may be an ideal candidate for obesity relief.
\end{abstract}

Key words : Hizikia fusiforme, 3T3-L1, obesity, adipogenesis, peroxisome proliferator-activated receptor $\gamma(\operatorname{PPAR} \gamma), \mathrm{CCAAT} / \mathrm{enhancer}$ binding protein $(\mathrm{C} / \mathrm{EBP})$

\section{서 론}

비만은 지방의 축적과 에너지 저장을 위한 조절과정에서 주로 발생하게 된다[17]. 고도비만의 경우에는 당뇨, 심혈관질 환, 고혈압, 고지혈증 등과 같은 심각한 성인병을 유발할 뿐만 아니라 각종 암의 발생빈도를 증가시키는 것으로 알려져 있으 므로 비만은 수명단축의 중요지표가 될 수 있다[9]. 따라서 이 러한 비만억제를 위하여 세포 내 지방의 축적을 예방하거나 축적된 지방을 분해하도록 자극하는 방안에 대한 연구가 최근 많은 관심을 끌고 있다. 일반적으로 비만은 지방전구세포의 분화와 같은 adipogenesis (지방세포 분화) 과정을 통하여 새 롭게 생성되는 지방세포의 비대 및 과형성에 의한 지방조직의 축적에 의하여 유발되는 것으로 알려져 있다[1,6]. 지방세포의 비대는 음식물에 포함되어 있는 triglyceride의 축적에 의하여 유발되며, 지방세포의 과형성은 세포증식 및 분화에 의해서 유발되는 것으로 알려져 있다[15].

지방전구세포가 지방세포로 분화되는 과정인 adipogenesis 는 세포형태, 호르몬 감수성 및 유전자 발현의 다양한 변화가

*Corresponding author

Tel : +82-51-890-1594, Fax : +82-51-890-2646

E-mail : hhj2001@deu.ac.kr
동반되는 복합적인 과정이다. 지방전구세포가 지방세포로 분 화되는 과정은 CCAAT/enhancer binding protein (C/EBP)에 속한 $\mathrm{C} / \mathrm{EBP} \beta$ 와 $\mathrm{C} / \mathrm{EBP} \delta$ 를 중심으로 조절되는 초기 분화와 peroxisome proliferator-activated receptor $\gamma$ (PPAR $\gamma$ )와 $\mathrm{C} / \mathrm{EBPa}$ 를 중심으로 조절되는 후기 분화로 나누어진다. 세포 분열유도물질(mitogen)이나 호르몬 등의 자극으로 초기 분화 가 시작되면 다양한 인자들에 의하여 $\mathrm{C} / \mathrm{EBP} \beta$ 와 $\mathrm{C} / \mathrm{EBP} \delta$ 의 발현이 증가한다[3,23]. 이렇게 증가된 $\mathrm{C} / \mathrm{EBP} \beta$ 와 $\mathrm{C} / \mathrm{EBP} \delta$ 는 서로 협동적으로 혹은 단독으로 작용하여 $\mathrm{PPAR} \gamma$ 와 $\mathrm{C} / \mathrm{EBPa}$ 의 발현을 조절하는 것으로 알려져 있다[2,19,20,22]. Adipogenesis의 master regulator로 불리는 PPAR $\gamma$ 와 $\mathrm{C} / \mathrm{EBPa}$ 는 서로 상호작용하여 상승효과를 가지며, 그 결과 adiponectin, glucose transporter (GLUT) 4, fatty acid synthase 등을 포함한 adipogenesis의 terminal marker의 발현을 증가시킨다[12,16]. Adipogenesis pathway에서 PPAR $\gamma$ 와 $\mathrm{C} / \mathrm{EBPa}$ 의 상위에 위치하는 $\mathrm{C} / \mathrm{EBP} \beta$ 와 $\mathrm{C} / \mathrm{EBP} \delta$ 는 세포분열 유도물질과 호르몬의 자극에 의해 분화 초기에 빠르게 증가되 어 $\mathrm{PPAR} \gamma$ 와 $\mathrm{C} / \mathrm{EBPa}$ 의 발현을 증가시키고 분화의 후기에는 감소한다[4,7]. $\mathrm{C} / \mathrm{EBP} \beta$ 와 $\mathrm{C} / \mathrm{EBP} \delta$ 이외에도 $\mathrm{PPAR} \gamma$ 와 C/EBP $a$ 의 상위에 위치한 다양한 지방 세포 형성 유도 조절자(pro-adipogenic regulator) 및 지방세포형성 억제 조절자(anti-adipo- 
genic regulator)들이 분화의 초기와 후기에 발현되거나 감소되 면서 adipogenesis를 조절하는 것으로 알려져 있다[16].

일반적으로 해조류는 육상식물과는 다른 환경에서 서식하 기 때문에 생체 내 2차 대사산물의 화학구조가 매우 독특하며, 해양천연물의 2 차 대사산물은 생리기능이나 생태계의 제어에 매우 중요한 생리활성 물질을 함유하고 있다. 또한 해조류는 소화율이 낮아서 열량원으로서의 가치는 적지만 포만감과 통 변을 조절하는 효과 뿐 만 아니라 필수아미노산 및 불포화지 방산의 함량이 높으며, 수용성 다당류로 구성되어 있는 식이 섬유소가 다량으로 함유되어 있으므로 면역력 증강, 항산화, 항돌연변이, 항혈액응고 및 항암 효과와 함께 인체에서의 지방 대사 완화에 중요한 역할을 하는 것으로 보고되어 있다[14,18]. 이러한 해조류 중에서 갈조식물문(Heterokontophyta), 모자반 과(Sargassaceae)에 속하는 다년생 해조류인 톳(Hizikia fusiformd은 평균 수면에서 저조선 약 $30 \mathrm{~cm}$ 위쪽의 조간대 하부 에 서식하며, 20-100 cm까지 성장한다. 다른 해조류에 비해 톳은 칼슘, 철, 요오드 같은 무기질, 비타민 등이 풍부하고 지 방 함량이 낮으며, 필수아미노산 함량과 불포화지방산의 함량 이 높다. 또한 식이 섬유소 함량은 건조무게의 33 75\%를 차지 하고, 그 중 17 59\%가 수용성 다당류로 구성되어 있다. 해조류 의 식이성 섬유소는 다양한 약리적 작용이외에, 지방대사 완 화에 중요한 역할을 하는 것으로 보고되어 있다[5,10,13]. 하지 만 톳 추출물이 유발하는 항비만 효과 및 비만억제와 연관된 구체적인 기전 연구는 거의 이루어져 있지 않은 상태이다.

따라서 본 연구에서는 3T3-L1 지방전구세포의 adipogenesis 과정에 있어서 톳 분획물이 유발하는 항비만 효과와 함께 그에 따른 생화학적 기전의 해석을 위하여 insulin, dexamethasone 및 3-isobutyl-1-methylxanthine (IBMX) 등의 비 만유도인자에 의하여 인위적으로 유발된 adipogenesis 과정 에 있어서 어떠한 영향을 미치는지를 조사하였고, 지방세포분 화에 관여하는 $\mathrm{PPAR} \gamma, \mathrm{C} / \mathrm{EBPa}$ 및 C/EBP $\beta$ 등과 같은 adipo- genic transcription factor들의 발현 변화 여부를 비교하였다.

\section{재료 및 방법}

\section{분획물의 제조}

본 실험에 사용된 톳은 2009년 기장군에서 채집된 것으로, 추출물을 얻기 위하여 흐르는 물로 24시간 동안 세척하여 염 분과 불순물을 제거하고 깨끗한 물로 수 회 세척한 후 그늘에 서 건조시켜 사용하였다. 건조된 톳을 $80 \%$ 에탄올에 24 시간 동안 침지시킨 후 환류 냉각시키면서 $80^{\circ} \mathrm{C}$ 수욕상에서 3 시간 씩 3회 반복 추출한 후 감압 추출 농축장치(EYELA, Japan)로 에탄올 추출물을 얻었다. 에탄올 추출물을 증류수에 현탁하 고, 분액깔때기에서 dichloromethane, ethyl acetate, butanol, water를 순차적으로 계층 분획한 뒤 여과 후 회전진공농축기 로 $45^{\circ} \mathrm{C}$ 에서 감압 농축하여 각각의 분획물을 얻었다(Fig. 1).

\section{실험재료}

mRNA 발현 양 분석을 위하여 사용된 Bioneer (Taejeon, Korea)에서 구입한 primer 염기서열은 Table 1에 나타내었으 며, 단백질 분석을 위하여 사용된 $\mathrm{PPAR} \gamma, \mathrm{C} / \mathrm{EBPa}, \mathrm{C} / \mathrm{EBP \beta}$ 및 actin 항체는 Santa Cruz Biotechnology Inc. (Santa Cruz, CA, USA) 및 Cell Signaling Technology (Beverly, Ma, USA) 에서 구입하였다. Immunoblotting을 위해 2차 항체로 사용된 peroxidase-labeled donkey anti-rabbit 및 peroxidase-labeled sheep anti-mouse immunoglobulin은 Amersham Life Science Corp. (Arlington Heights, IL, USA)에서 구입하였다. 또한 3T3-L1 지방전구세포의 분화를 위하여 사용된 insulin, dexamethasone 및 IBMX와 지방세포 내 triglyceride (TG) 생 성을 확인하기 위하여 사용된 Oil Red O는 Sigma-Aldrich (St. Luis, MO, USA)에서 구입하였다.

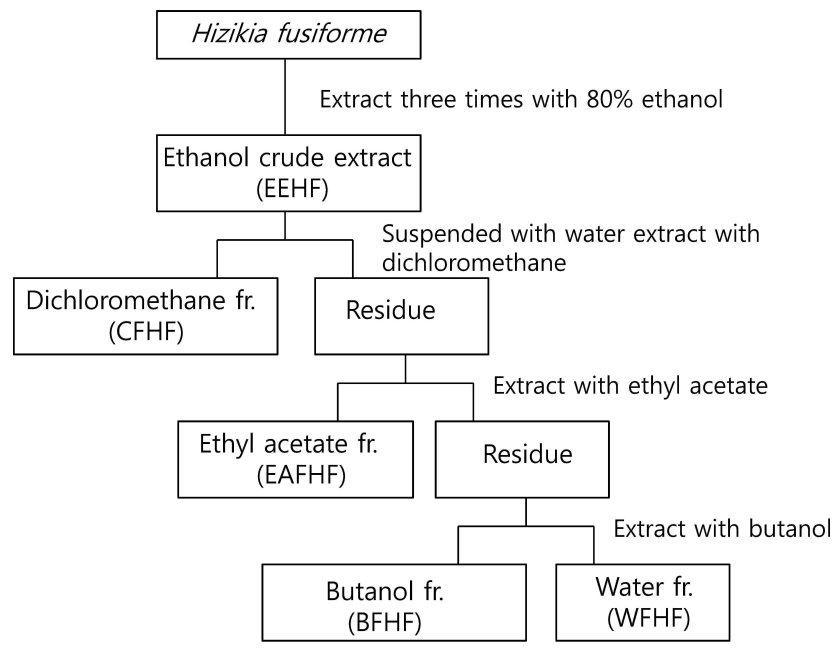

Fig. 1. Fractionation procedure of $H$ fusiforme. Fractionations were separated by separatory funnel. 
Table 1. Sequence of primers used for RT-PCR

\begin{tabular}{|c|c|c|}
\hline Gene name & & Sequence \\
\hline \multirow{2}{*}{ GAPDH } & Sense & 5'-CGG-AGT-CAA-CGG-ATT-TGG-TCG-TAT-3' \\
\hline & Antisense & 5'-AGC-CTT-CTC-CAT-GGT-GGT-GAA-GAC-3' \\
\hline \multirow{2}{*}{ PPAR $\gamma$} & Sense & 5'-CGC-TGA-TGC-ACT-GCC-TAT-GA-3' \\
\hline & Antisense & 5'-TGC-GAG-TGG-TCT-TCC-ATC-AC-3' \\
\hline \multirow{2}{*}{$\mathrm{C} / \mathrm{EBPa}$} & Sense & 5'-GTG-TGC-ACG-TCT-ATG-CTA-AAC-CA-3' \\
\hline & Antisense & 5'-GCC-GTT-AGT-GAA-GAG-TCT-CAG-TTT-G-3' \\
\hline \multirow{2}{*}{$\mathrm{C} / \mathrm{EBP} \beta$} & Sense & 5'-GTT-TCG-GGA-GTT-GAT-GCA-ATC-3' \\
\hline & Antisense & 5'-AAC-AAC-CCC-GCA-GGA-ACA-T-3' \\
\hline
\end{tabular}

\section{T3-L1 지방전구세포의 배양}

실험에 사용된 3T3-L1 지방전구세포는 90\%의 Dulbecco's Modified EaDCRT Media (DMEM, Gibco BRL, Grand Island, NY, USA), $10 \%$ 의 bovine calf serum (BCS, Gibco BRL) 및 $1 \%$ 의 penicillin 및 streptomycin (Gibco BRL)이 포함된 배지 를 사용하여 $37^{\circ} \mathrm{C}, 5 \% \mathrm{CO}_{2}$ 조건 하에서 배양하였다. 세포수의 증식에 따른 과밀도 현상을 해소하기 위하여 성장배지의 교환 을 매 48 시간마다 실시하여 적정 수의 세포를 유지하였다.

\section{T3-L1 지방전구세포의 분화유도}

3T3-L1 지방전구세포를 세포 배양용 6 well plate에서 confluent 상태까지 배양한 후 $10 \mu \mathrm{g} / \mathrm{ml}$ insulin, $0.1 \mu \mathrm{M}$ dexamethasone 및 $0.5 \mathrm{mM} \mathrm{IBMX}$ 이 포함된 분화배지로 교환하여 2일간 배양하였으며, 그 후 매 2일마다 $10 \mu \mathrm{g} / \mathrm{ml}$ insulin이 포함된 배지로 교환하였다. Adipogenesis의 진행과정에서 톳 분획물의 영향을 확인하기 위해, 첫 번째 분화유도를 할 때 톳 분획물을 함께 처리하였다.

MTT assay에 의한 3T3-L1 지방전구세포 성장억제 조사

세포 배양용 6 well plate에 3T3-L1 지방전구세포를 분주하 여 confluent 상태까지 배양한 후 톳 추출물을 배지에 희석하 여 각 well 당 적정농도로 처리하였다. 72 시간 후 희석된 0.5 $\mathrm{mg} / \mathrm{ml}$ 농도의 tetrazolium bromide salt (MTT, Amresco, Solon, $\mathrm{OH}, \mathrm{USA}$ )를 $200 \mu \mathrm{l}$ 씩 분주하고 2시간 동안 $\mathrm{CO}_{2}$ incubator에서 배양시킨 다음 배지와 MTT 시약을 깨끗하게 제 거하고 $\mathrm{DMSO}$ 를 $1 \mathrm{ml}$ 씩 분주하여 well에 생성된 formazan을 모두 녹인 후 96 well plate에 $200 \mu$ 씩 옮겨서 ELISA reader (Molecular Devices, Sunnyvale, CA, USA)로 $540 \mathrm{~nm}$ 에서 흡 광도를 측정하였다. 각 세포에 대한 독성은 각각의 대조군의 평균 흡광도 값을 구하여 평균 흡광도 값에 대한 백분율로 나타내었다.

\section{T3-L1 지방전구세포 형태의 관찰}

톳 추출물 처리에 의한 3T3-L1 지방전구세포의 분화 및 droplet 생성 정도를 확인하기 위하여 세포 배양용 6 well plate에 3T3-L1 지방전구세포를 분주하여 confluent 상태까지
배양한 후 톳 추출물을 적정농도로 희석 처리하면서 분화를 유도하였다. 분화가 끝난 후 톳 추출물 처리농도에 따른 분화 및 droplet 생성 정도를 도립 현미경을 이용하여 200배의 배율 로 관찰하였다.

\section{Oil Red O 염색 및 정량}

세포 내 droplet 생성을 확인하기 위하여 Oil Red O 염색을 실시하였다. 준비된 3T3-L1 지방전구세포를 PBS로 세척한 후 $3.7 \%$ formalin으로 10분간 고정하고 $60 \%$ isopropanol을 이용 하여 세척한 다음 Oil Red O solution을 처리하여 실온에서 20 분 간 염색하였다. 염색 후 Oil Red O solution을 제거하고 증류수로 4 회 세척한 다음 염색된 세포를 위상차 현미경을 이용하여 관찰하였다. 또한 정량적 분석을 위하여 $100 \%$ isopropanol을 이용하여 지방을 추출한 후 96 well plate에 200 $\mu \mathrm{l}$ 씩 옮겨서 ELISA reader로 $500 \mathrm{~nm}$ 에서 흡광도를 측정하였 고 대조군의 흡광도 값에 대한 백분율로 나타내었다.

\section{Reverse transcriptase-polymerase chain reaction (RT-PCR)에 의한 mRNA의 분석 \\ 톳 분획물을 처리하면서 분화시킨 3T3-L1 지방전구세포에} TRIzol reagent (Invitrogen Co., Carlsbad, Ca, USA) $1 \mathrm{ml}$ 을 첨가하여 $4^{\circ} \mathrm{C}$ 에서 1 시간 동안 반응시킨 후 $200 \mu \mathrm{l}$ 의 chloroform을 첨가하여 $4^{\circ} \mathrm{C}$ 에서 30 분 동안 반응시켰다. $14,000 \mathrm{rpm}$, $4{ }^{\circ} \mathrm{C}$ 에서 15 분간 원심분리시켜 $400 \mu 1$ 의 상층액을 분리하고 동 량의 isopropanol을 첨가하여 $4^{\circ} \mathrm{C}$ 에서 30 분 동안 반응시킨 후 $14,000 \mathrm{rpm}, 4^{\circ} \mathrm{C}$ 에서 30 분간 원심분리시켜 total RNA를 분리 하였다. 분리된 RNA를 DEPC water를 이용하여 녹이고 정량 한 후, 각각의 primer, DEPC water 그리고 ONE-STEP RT-PCR PreMix Kit (Intron, Korea)를 넣고 Mastercycler gradient (Eppendorf, Hamburg, Germany)를 이용하여 역전사 및 증폭하였다. 각 $\mathrm{PCR}$ 산물들의 양적 차이를 확인하기 위하 여 1X TAE buffer로 1\% agarose gel을 만들고 well 당 각각의 primer에 해당하는 PCR 산물에 DNA gel loading solution을 섞어서 loading 한 후 $100 \mathrm{~V}$ 에서 전기영동을 하였다. 전기영동 으로 DNA 분리가 끝난 gel을 ethidium bromide $(\mathrm{EtBr}$, Sigma-Aldrich)을 이용하여 염색한 후 UV 하에서 확인하였으 
며, housedeeping 유전자인 glyceraldegyde-3-phosphate dehydrogenase (GAPDH)를 internal control로 사용하였다.

\section{Western blot analysis에 의한 단백질 발현의 분석}

동일한 방법으로 준비된 3T3-L1 지방전구세포에 적당량의 lysis buffer [25 mM Tris-Cl (pH 7.5), $250 \mathrm{mM} \mathrm{NaCl}, 5 \mathrm{mM}$ EDTA, 1\% NP-40, $1 \mathrm{mM}$ phenymethylsulfonyl fluoride (PMSF), $5 \mathrm{mM}$ dithiothreitol (DTT)]를 첨가하여 $4^{\circ} \mathrm{C}$ 에서 1시 간 동안 반응시킨 후, $14,000 \mathrm{rpm}$ 으로 30 분간 원심분리하여 상층액에 있는 총 단백질을 분리하였다. 상층액의 단백질 농 도는 Bio-Rad 단백질 정량 시약(Bio-Rad, Hercules, CA, USA) 과 그 사용방법에 따라 정량 한 다음 동량의 Laemmli sample buffer (Bio-Rad)를 섞어서 sample을 만들었다. 동량의 sam-
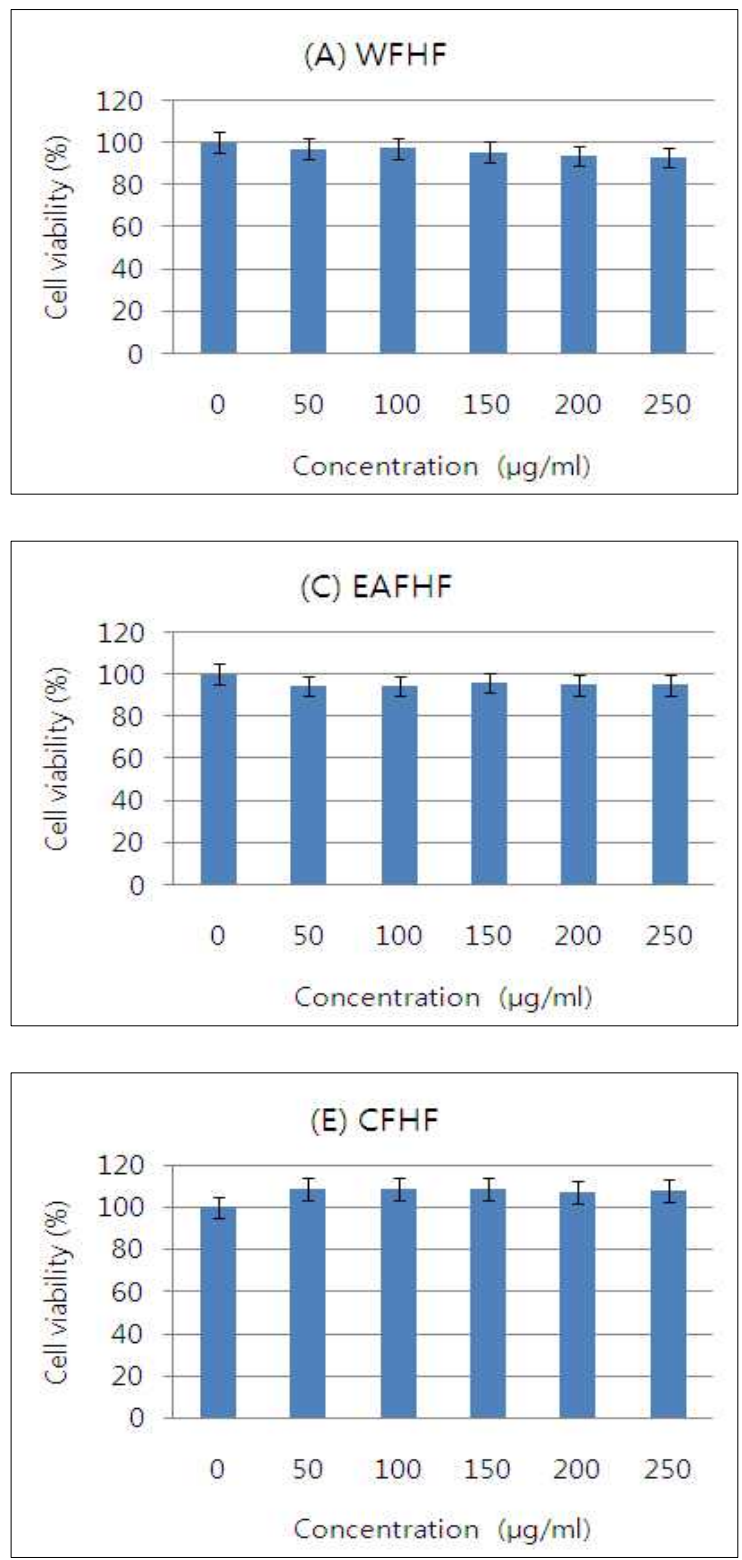

ple을 sodium dodecyl sulphate (SDS)-polyacrylamide gel을 이용하여 전기영동으로 분리한 후, nitrocellulose membrane (Schleicher and Schuell, Keene, NG, USA)으로 electroblotting에 의해 전이시켰다. 분리된 단백질이 전이된 nitrocellulose membrane에 $5 \%$ skim milk를 처리하여 비특이적인 단백질들에 대한 blocking을 실시하고 1차 항체를 처리하여 상온에서 2시간 이상 또는 $4^{\circ} \mathrm{C}$ 에서 over night 시킨 다음 PBS-T로 세척하고 처리된 1 차 항체에 맞는 2 차 항체를 사용하 여 상온에서 1 시간 정도 반응시켰다. 반응이 끝난 후 암실에서 Enhanced Chemiluminoesence (ECL) solution (Amersham Life Science Corp.)을 적용시킨 다음 X-ray film에 감광시켜 특정 단백질의 발현 양을 분석하였다.
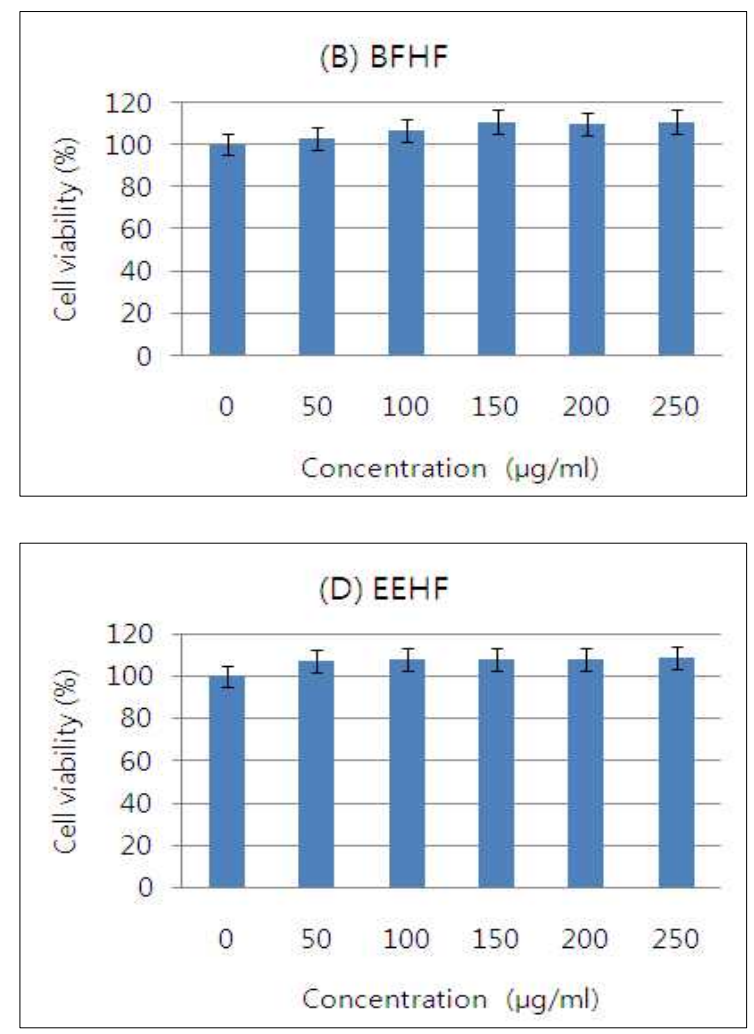

Fig. 2. Effects of various extracts of $H$ fusiforme on the cell growth in 3T3-L1 mouse preadipocytes. Cells were treated with the indicated concentrations of $H$ fusiforme extracts for $72 \mathrm{hr}$. Cell viability was determined by MTT assay, respectively. Results are expressed as percentage of the vehicle treated control $\pm \mathrm{SD}$ of three separate experiments. (A) WFHF, water extracts of $H$ fusiforme, (B) BFHF, butanol extracts of $H$ fusiforme, (C) EAFHF, ethyl acetate extracts of $H$. fusiforme, (D) EEHF, ethanol extracts of $H$. fusiforme, (E) CFHF, dichloromethane extracts of $H$. fusiforme 


\section{Statistical analysis}

모든 실험 결과는 Statistical Package for the Social Sciences (SPSS) 통계 프로그램을 이용하여 평균(mean) \pm 표준편차 (S.D.)로 나타냈다. 각 실험군의 분석 항목별 통계의 유의성은 Student t-test를 이용하여 $p<0.05$ 수준에서 검증하였다.

\section{결과 및 고찰}

\section{T3-L1 지방전구세포의 증식에 미치는 톳 분획물의 영향}

3T3-L1 지방전구세포에서 톳 추출물들의 세포독성을 조사 하기 위해서 50 250 $\mu \mathrm{g} / \mathrm{ml}$ 의 농도에서 MTT assay 실험을 수행하였다. MTT assay는 탈수소 효소작용에 의해 노란색의 수용성 기질인 MTT tetrazolium을 청자색의 formazan으로 환원시키는 미토콘드리아의 능력을 이용하는 검사법으로서 세포의 증식과 성장을 알아보는 대표적인 실험방법 중 하나로 살아있는 세포 수에 비례해서 흡광도가 증가한다. 톳 분획물 들의 농도에 따른 3T3-L1 세포의 증식에 미치는 영향을 MTT assay로 분석한 결과는 Fig. 2에 나타낸 바와 같다. 결과에서 알 수 있듯이 WFHF 및 $\mathrm{EAFHF}$ 분획물 처리군의 경우 전체적
으로 생존율의 변화가 거의 나타나지 않은 반면에 BFHF, $\mathrm{EEHF}$ 및 $\mathrm{CFHF}$ 분획물 처리군의 경우에는 세포증식 변화율 이 증가하는 경향을 보였다. 이상의 결과를 살펴볼 때 3T3-L1 지방전구세포에서 $250 \mu \mathrm{g} / \mathrm{ml}$ 이하의 톳 분획물들에 의한 세 포독성은 거의 나타나지 않는 것으로 나타났다.

3T3-L1 지방전구세포의 lipid droplet 및 TG 생성에 미 치는 톳 분획물의 영향

Phospholipid monolayer에 의하여 둘러싸여진 중성지방으 로 구성된 비활성 소낭인 lipid droplet은 precursor fibroblast 에서부터 지방세포로의 분화과정에서 나타나며, 이렇게 생성 된 lipid droplet은 lipoprotein lipase (LPL)에 의한 TG 유입과 adipose triglyceride lipase (ATGL) 및 hormone sensitive lipase (HSL)에 의한 TG 유출에 의하여 조절되는 것으로 알려 져 있다[11,24]. 따라서 본 연구에서는 3T3-L1 지방전구세포가 지방세포로의 분화과정에 나타나는 lipid droplet 생성에 톳 분획물이 어떠한 영향을 미치는지를 확인하기 위하여 각각의 분획물을 적정 농도로 처리하여 분화를 유도한 후 Oil Red $\mathrm{O}$ 염색 전후로 구분하여 lipid droplet 생성정도를 관찰하였

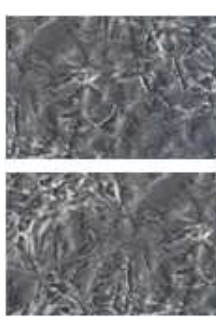

Con

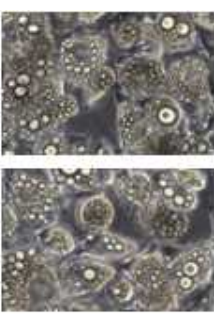

MDI

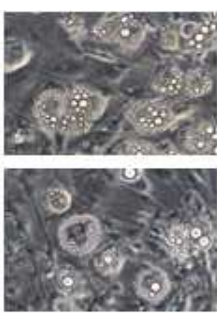

WFHF

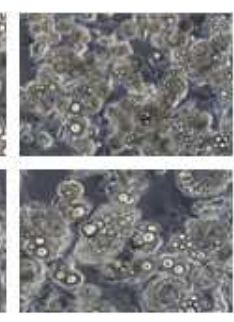

BFHF

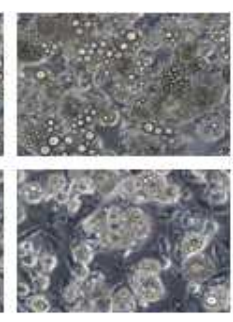

EAFHF

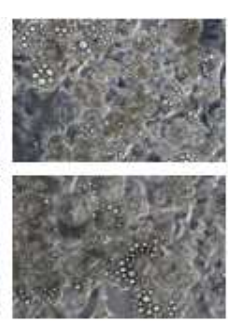

EEHF

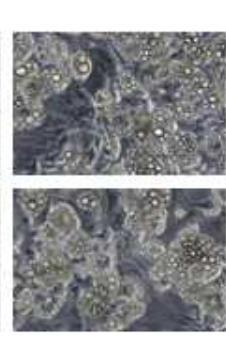

$(\mu \mathrm{g} / \mathrm{ml})$

200

CFHF

Fig. 3. Effects of $H$. fusiforme extracts on the microscopic morphological changes of differentiated 3T3-L1 mouse preadipocytes. Differentiation of confluent 3T3-L1 mouse preadipocytes was initiated with MDI (0.5 mM 3-isobytyl-1-methylxanthine, 10 $\mu \mathrm{M}$ dexamethasone, and $10 \mu \mathrm{g} / \mathrm{mL}$ insulin) and maintained DMEM-5\% FBS medium in the absence or presence of $H$ fusiform extracts. After day 8, differentiating 3T3-L1 cells were visualized by light microscopy. Magnification, $\times 200$. Groups were refered to Fig. 2.

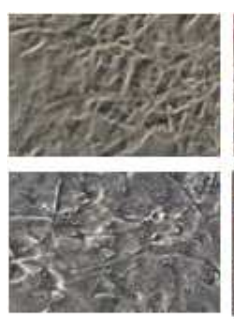

Con

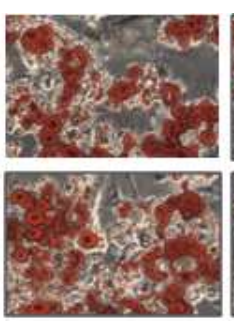

MDI

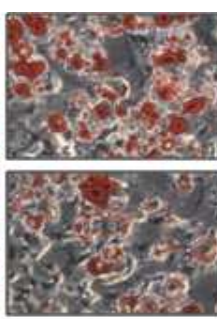

WFHF

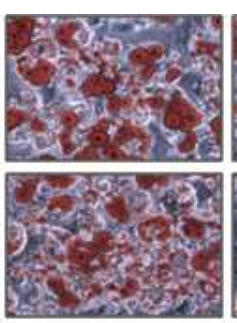

BFHF

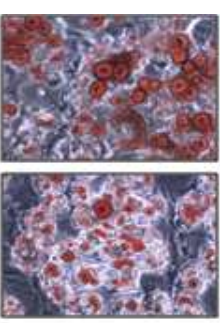

EAFHF
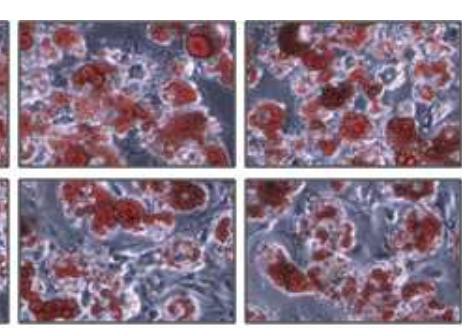

$(\mu \mathrm{g} / \mathrm{ml})$

200

EEHF

CFHF

Fig. 4. Inhibitory effects of $H$. fusiforme extracts on lipid droplet accumulation of differentiated 3T3-L1 mouse preadipocytes. Differentiation of confluent 3T3-L1 mouse preadipocytes was initiated with MDI and maintained DMEM-5\% FBS medium (maintenance differentiation medium) in the absence or presence of $H$. fusiforme extracts. After day 8, cells were fixed and stained with Oil Red $O$ to visualize lipid droplets by light microscopy. Magnification, $\times 200$. Groups were refered to Fig. 2 . 
다. Fig. 3 및 4 에서 볼 수 있듯이 톳 분획물을 처리하지 않고 분화를 유도하였을 경우에 세포질 내 lipid droplet의 형성이 활발하게 유발되었으며, 톳 분획물 처리에 의하여 lipid droplet의 형성이 전체적으로 현저히 억제되는 것을 확인하였는데, 특히 WFHF 처리군에서 lipid droplet 억제 현상이 강하게 나 타났다.

중성지방으로 알려진 $\mathrm{TG}$ 의 저장은 chylomicron 및 very low density lipoprotein (VLDL) 등과 같은 TG-rich lipoprotein에 의하여 유발되며, 에너지원으로 사용되고 남은 TG 의 경우에는 지방세포에 흡수되고 저장되어 비만의 원인이 된다[8,21]. 따라서 본 연구에서는 3T3-L1 지방전구세포에 각 각의 톳 분획물을 처리하였을 경우 유발되는 TG의 생성억제 효과를 직접 확인한 결과, Fig. 5 에 나타난 바와 같이 정상배지 에서 분화된 지방세포에 비교해서 WFHF $100 \mathrm{\mu g} / \mathrm{ml}$ 및 200 $\mathrm{\mu g} / \mathrm{ml}$ 처리군에서 각각 $26.8 \%$ 와 $42.6 \%$ 의 TG 생성 억제효과 가 나타났다. 또한 BFHF, EAFHF, EEHF 및 CFHF $200 \mu \mathrm{g} / \mathrm{ml}$ 처리군의 경우에는 각각 $13 \%, 18 \%, 17.4 \%$ 및 $23.7 \%$ 의 TG 생성 억제효과를 보였다. 이상의 결과를 살펴 볼 때 다섯 종류의 톳 분획물 모두 TG 생성 억제효과가 있는 것으로 나타났고, 특히 WFHF의 TG 생성 억제효과가 큰 것으로 나타났다.

Adipogenic transcription factor의 발현에 미치는 톳 추출물의 영향

지방전구세포에서 지방세포로 분화되는 adipogenesis 과정 에는 많은 종류의 adipogenic transcription factor들이 작용한 다. 그중에서 $\mathrm{C} / \mathrm{EBP} \beta$ 는 $\mathrm{C} / \mathrm{EBPa}$ 와 $\mathrm{PPAR} \gamma$ 를 조절하는 대표 적인 전사 인자이며[4,7], $\mathrm{PPAR} \gamma$ 와 $\mathrm{C} / \mathrm{EBPa}$ 는 adipogenesis

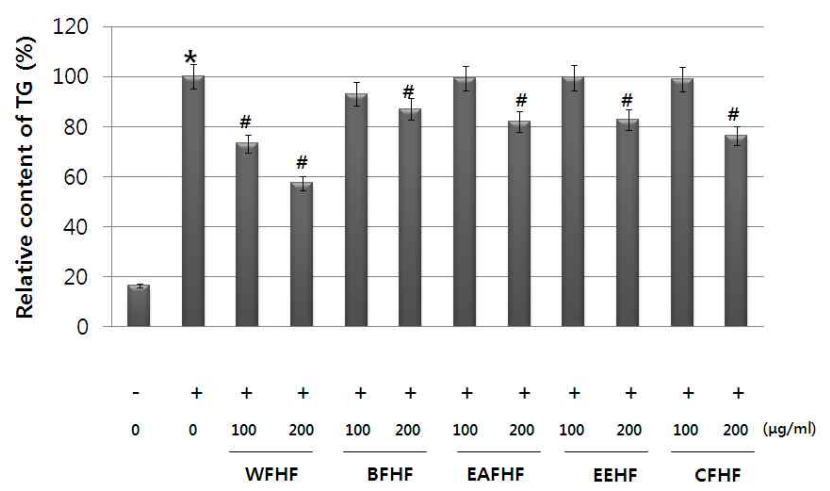

Fig. 5. Inhibitory effects of $H$. fusiforme extracts on triglyceride accumulation of differentiated 3T3-L1 mouse preadipocytes. Triglyceride contents were determined by Oil Red O staining after treatment of the absence or presence of $H$. fusiforme extracts. The rates of triglyceride contents were measured at $\lambda=500 \mathrm{~nm}$ wavelength by the ELISA reader. Data are expressed as the means \pm S.D. *: $p<0.05$ vs untreated control. \#: $p<0.05$ vs MDI treated group. Groups were refered to Fig. 2.
를 조절하는 핵심 전사인자로서 분화의 후기에 높게 발현되어 adiponectin과 GLUT4 등을 포함한 adipogenesis의 terminal marker의 발현을 유도하는 것으로 알려져 있다[12]. 이렇게 분화된 세포는 lipid droplet 생성 및 세포의 크기 증가 등과 같은 형태적 특징과 더불어 특이적인 유전자의 발현을 유발함 으로서 지방세포의 특징을 지니게 된다. 따라서 본 연구에서 는 톳 분획물들이 adipogenic transcription factor들의 발현에 어떠한 영향을 미치는 지를 mRNA 및 단백질 수준에서 확인 하였다. Fig. 6에 나타난 바와 같이 분화유도인자인 insulin, dexamethasone 및 IBMX를 처리하여 분화를 유발하였을 경우 $\mathrm{PPAR} \gamma, \mathrm{C} / \mathrm{EBPa}$ 및 $\mathrm{C} / \mathrm{EBP} \beta$ 의 발현이 현저하게 증가하는 것 으로 나타났으며, 이러한 분화유도 과정에서 여러 종류의 톳 분획 물들을 처리하였을 경우 $100 \mathrm{\mu g} / \mathrm{ml}$ 의 농도보다 $200 \mathrm{\mu g} / \mathrm{ml}$ 의

A) WFHF BFHF EAFHF EEHF CFHF $0 \quad 0 \overline{100200} \overline{100200} \overline{100200} \overline{100200} \overline{100200}(\mu \mathrm{g} / \mathrm{ml})$

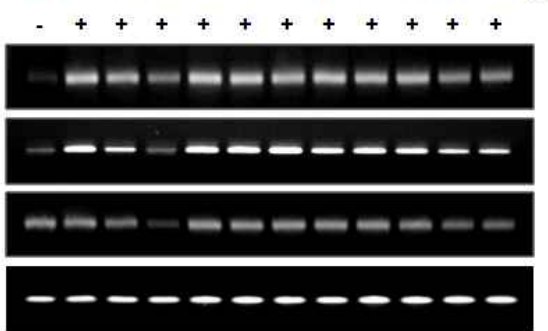

PPAR-gamma C/EBP-alpha c/EBP-beta GAPDH

B)
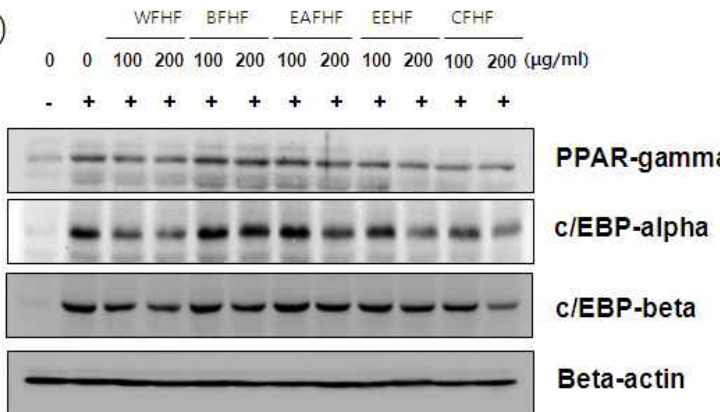

Fig. 6. Effects of $H$. fusiforme extracts on the levels of adipogenic transcription factors mRNA and protein expression in differentiated 3T3-L1 mouse preadipocytes. Differentiation of confluent 3T3-L1 mouse preadipocytes was incubated with the absence or presence of $H$. fusiforme extracts for 8 day after initiated with MDI. (A) Total RNAs were isolated and reverse- transcribed. The resulting CDNAs were subjected to PCR with the indicated primers and the reaction products were subjected to electrophoresis in 1\% agarose gel and visualized by $\mathrm{EtBr}$ staining. GAPDH was used as an internal control. (B) Cells were lysed and cellular proteins were separated by SDS-polyacrylamide gels and transferred onto nitrocellulose membranes. The membranes were probed with the indicated antibodies. Proteins were visualized using an ECL detection system. Actin was used as an internal control. Groups were refered to Fig. 2. 
처리군에서 PPAR $\gamma, \mathrm{C} / \mathrm{EBPa}$ 및 C/EBP $\beta$ 의 발현이 mRNA 및 단백질 수준에서 감소하였으며, 특히 WFHF 처리군에서 $\mathrm{PPAR} \gamma, \mathrm{C} / \mathrm{EBPa}$ 및 $\mathrm{C} / \mathrm{EBP \beta}$ 의 발현이 현저하게 감소되는 것을 확인할 수 있었다. 이상의 결과를 살펴볼 때 다섯 종류의 톳 분획물 중, 특히 WFHF 처리군이 3T3-L1 지방전구세포에 서 adipogenic transcription factor인 PPAR $\gamma, \mathrm{C} / \mathrm{EBPa}$ 및 $\mathrm{C} / \mathrm{EBP} \beta$ 의 발현을 효과적으로 억제하여 lipid droplet 및 TG 생성을 감소시킴으로서 지방세포로의 분화를 억제시킨다는 것을 알 수 있었다.

\section{감사의 글}

본 연구는 블루바이오 소재 개발 및 실용화 지원 센터 (RIC08-06-07)의 지원에 의해 이루어진 것임.

\section{References}

1. Alessi, M. C., Lijnen, H. R., Bastelica, D. and Juhan-Vague, I. 2003. Adipose tissue and atherothrombosis. Pathophysiol. Haemost. Thromb. 33, 290-297.

2. Cao, Z., Umek, R. M. and McKnight, S. L. 1991. Regulated expression of three $\mathrm{C} / \mathrm{EBP}$ isoforms during adipose conversion of 3T3-L1 cells. Genes Dev. 5, 1538-1552.

3. Chen, Z., Torrens, J. I., Anand, A., Spiegelman, B. M. and Friedman, J. M. 2005. Krox20 stimulates adipogenesis via C/EBPbeta-dependent and -independent mechanisms. Cell Metab. 1, 93-106.

4. Christy, R. J., Kaestner, K. H., Geiman, D. E. and Lane, M. D. 1991. CCAAT/enhancer binding protein gene promoter: binding of nuclear factors during differentiation of 3T3-L1 preadipocytes. Proc. Natl. Acad Sci. USA. 88, 2593-2597.

5. Dobashi, K., Nishino, T., Fujihara, M. and Nagumo, T. 1989. Isolation and preliminary characterization of fucose-containing sulfated polysaccharides with blood-anticoagulant activity from the brown seaweed Hizikia fusiforme Carbohydr. Res. 194, 315-320.

6. Gesta, S., Tseng, Y. H. and Kahn, C. R. 2007. Developmental origin of fat: tracking obesity to its source. Cell 131, 242-256.

7. Hamm, J. K., Park, B. H. and Farmer, S. R. 2001. A role for $\mathrm{C} / \mathrm{EBPbeta}$ in regulating peroxisome proliferatoractivated receptor gamma activity during adipogenesis in 3T3-L1 preadipocytes. J. Biol. Chem 276, 18464-18471.

8. Labreuche, J., Touboul, P. J. and Amarenco, P. 2009. Plasma triglyceride levels and risk of stroke and carotid atherosclerosis: a systematic review of the epidemiological studies. Atherosclerosis 203, 331-345.

9. Lew, E. A. 1985. Mortality and weight: insured lives and the American Cancer Society studies. Ann. Intern. Med 103, 1024-1029.

10. Li, B., Wei, X. J., Sun, J. L. and Xu, S. Y. 2006. Structural investigation of a fucoidan containing a fucose-free core from the brown seaweed, Hizikia fusiforme Carbohydr. Res. 341, 1135-1146.
11. Manickam, E., Sinclair, A. J. and Cameron-Smith, D. 2010. Suppressive actions of eicosapentaenoic acid on lipid droplet formation in 3T3-L1 adipocytes. Lipids Health Dis. 9, 57.

12. Morrison, R. F. and Farmer, S. R. 2000. Hormonal signaling and transcriptional control of adipocyte differentiation. $J$. Nutr. 130, 3116S-3121S.

13. Okai, Y., Higashi-Okai, K., Ishizaka, S. and Yamashita, U. 1997. Enhancing effect of polysaccharides from an edible brown alga, Hijikia fusiforme (Hijiki), on release of tumor necrosis factor-alpha from macrophages of endotoxin-nonresponder $\mathrm{C} 3 \mathrm{H} / \mathrm{HeJ}$ mice. Nutr. Cancer 27, 74-79.

14. Owen, T. A., Aronow, M., Shalhoub, V., Barone, L. M., Wilming, L., Tassinari, M. S., Kennedy, M. B., Pockwinse, S., Lian, J. B. and Stein, G. S. 1900. Progressive development of the rat osteoblast phenotype in vitro reciprocal relationships in expression of genes associated with osteoblast proliferation and differentiation during formation of the bone extracellular matrix. J. Cell. Physiol. 143, 420-430.

15. Roncari, D. A., Lau, D. C. and Kindler, S. 1981. Exaggerated replication in culture of adipocyte precursors from massively obese persons. Metabolism 30, 425-427.

16. Rosen, E. D. and MacDougald, O. A. 2006. Adipocyte differentiation from the inside out. Nat. Rev. Mol. Cell. Biol. 7, 885-896.

17. Spiegelman, B. M. and Flier, J. S. 1996. Adipogenesis and obesity: rounding out the big picture. Cell 87, 377-389.

18. Stroheker, T., Cabaton, N., Berges, R., Lamothe, V., Lhuguenot, J. C. and Chagnon, M. C. 2003. Influence of dietary soy isoflavones on the accessory sex organs of the Wistar rat. Food Chem Toxicol. 41, 1175-1183.

19. $\mathrm{Wu}, \mathrm{Z}$., Bucher, N. L. and Farmer, S. R. 1996. Induction of peroxisome proliferator-activated receptor gamma during the conversion of 3T3 fibroblasts into adipocytes is mediated by C/EBPbeta, C/EBPdelta, and glucocorticoids. Mol. Cell. Biol. 16, 4128-4136.

20. Wu, Z., Xie, Y., Bucher, N. L. and Farmer, S. R. 1995. Conditional ectopic expression of C/EBP beta in NIH-3T3 cells induces PPAR gamma and stimulates adipogenesis. Genes Dev. 9, 2350-2363.

21. Yano, T., Kobori, S., Sakai, M., Anami, Y., Matsumura, T., Matsuda, H., Kasho, M. and Shichiri, M. 1997. Beta-very low density lipoprotein induces triglyceride accumulation through receptor mediated endocytotic pathway in 3T3-L1 adipocytes. Atherosclerosis 135, 57-64.

22. Yeh, W. C., Cao, Z., Classon, M. and McKnight, S. L. 1995. Cascade regulation of terminal adipocyte differentiation by three members of the C/EBP family of leucine zipper proteins. Genes Dev. 9, 168-181.

23. Zhang, J. W., Klemm, D. J., Vinson, C. and Lane, M. D. 2004. Role of CREB in transcriptional regulation of CCAAT/enhancer-binding protein beta gene during adipogenesis. J. Biol. Chem 279, 4471-4478.

24. Zimmermann, R., Strauss, J. G., Haemmerle, G., Schoiswohl, G., Birner-Gruenberger, R., Riederer, M., Lass, A., Neuberger, G., Eisenhaber, F., Hermetter, A. and Zechner, R. 2004. Fat mobilization in adipose tissue is promoted by adipose triglyceride lipase. Science 306, 1383-1386. 
초록 : 톳 분획물이 3T3-L1 지방전구세포의 분화 및 지방생성의 억제에 미치는 영향

최은옥 ${ }^{1,2} \cdot$ 김향숙, ${ }^{1,2}$ 한민호 ${ }^{3} \cdot$ 최영현 ${ }^{2,3,4} \cdot$ 김병우, ${ }^{4,5}$ 황진이 ${ }^{6} \cdot$ 황혜진 ${ }^{1,4} \star{ }_{\star}$

( ${ }^{1}$ 동의대학교 생활과학대학 식품영양학과, ${ }^{2}$ 항노화연구소, ${ }^{3}$ 한의학과, ${ }^{4}$ 블루바이오소재개발센터, ${ }^{5}$ 자연과학 대학 생명응용학과, ${ }^{6}$ 명지대학교 식품영양학과)

본 연구에서는 톳 분획물의 항비만 효과 및 그에 따른 생화학적 기전의 해석을 위하여 톳 분획물이 비만유도인 자에 의하여 인위적으로 유발된 adipogenesis 과정에 있어서 어떠한 영향을 미치는 지를 조사하였고, 이때 PPAR $\gamma, \mathrm{C} / \mathrm{EBPa}$ 및 C/EBP $\beta$ 등과 같은 adipogenic transcription factor들의 발현에 어떠한 변화가 유발되었는지를 조사하였다. 각각의 톳 분획물들이 성숙한 지방세포에서 나타나는 lipid droplet 및 TG 생성에 어떠한 영향을 미 치는 지를 확인한 결과, 모든 분획물에서 lipid droplet 및 TG 생성억제가 나타났지만 특히 WFHF 처리군에서 이러한 현상이 가장 강하게 나타났다. 또한 lipid droplet 및 TG 생성에 중요한 역할을 하는 것으로 알려진 adipogenic transcription factor들의 발현에 각각의 분획물들이 어떠한 영향을 미치는 지를 확인한 결과, WFHF 처리군에 서 PPAR $\gamma, \mathrm{C} / \mathrm{EBPa}$ 및 $\mathrm{C} / \mathrm{EBP} \beta$ 의 발현이 현저하게 감소하였음을 확인하였다. 이상의 결과를 종합해 보면 다섯 종류의 톳 분획물 모두 비만억제 효과가 있는 것으로 나타났고 특히 WFHF의 비만억제 효과가 강하게 나타났음 을 알 수 있었다. 본 연구 결과는 톳의 비만억제 가능성을 제시하는 것으로서 항비만 기전에 대한 생화학적 해석 및 이를 활용한 향후 지속적인 연구를 위한 자료로서 그 가치가 매우 높을 것으로 생각된다. 